\title{
Efficacy of first time furosemide use in thoroughbred racehorses in Brazil
}

\author{
Eficácia do primeiro uso da furosemida em cavalos de corrida da raça Puro-Sangue Inglês no Brasil
}

Maria Fernanda De Mello Costa ${ }^{\dagger *}$, Juliana N.P. Pereira *, Garry A. Anderson"

\begin{abstract}
Resumo
Como citar esse artigo. De Mello Costa, MF; Pereira, JNP, Anderson, GA Efficacy of first time furosemide use in thoroughbred racehorses in Brazil Revista de Saúde. 2018 Jan./Jun.; 09 (1): 02-03.

Cavalos de corrida são comumente afetados por uma condição denomidada Hemorraga Pulmonar Induzida por Esforço (HPIE), que consiste no rompimento das membranas alevolares e extravazamento de sangue para as vias aéreas. Considerase que a HPIE afeta negativamente o desempenho atlético dos cavalos de corrida e não há, atualmente, tratamento para a condição. Para reduzir a quantidade de sangramento, o diurético furosemida tem sido utilizado antes de exercício e competição em alguns hipódromos. A eficácia da furosemida em reduzir a HPIE foi documentada neste trabalho através da observação endoscópica das vias aéreas de equinos positivos para HPIE após duas corridas consecutivas.

Palavras-chave: Endoscopia; Cavalos de corrida; Hemorragia Pulmonar Induzida por Esforço; Terapêutica.
\end{abstract}

\begin{abstract}
Racehorses are commonly affected by a condition known as Exercise Induced Pulmonary Haemorrhage (EIPH) which consists of rupture of alveolar membranes and extravasation of blood into the airways. EIPH is considered to negatively affect racehorse performance and there is no current treatment. In order to reduce the amount of bleeding the diuretic furosemide has been used prior to exercise and competition in some racing jurisdictions. Efficacy of furosemide in reducing EIPH is documented in this research through endoscopic observation of the airways of horses positive for EIPH in two consecutive races.
\end{abstract}

Keywords: Endoscopy; Exercise Induced Pulmonary Haemorrhage; Therapy; Racehorses.

\section{Introdução}

Exercise Induced Pulmonary Haemorrhage is a condition affecting racehorses and other mammals subjected to running at high speeds. It is characterized by stress failure of alveolar capillaries ${ }^{1}$ with subsequent bleeding into the airways. Evaluation of EIPH is conducted mainly by respiratory endoscopy after exercise, with visualisation of blood in the trachea. Prophylaxis of Exercise Induced Pulmonary Haemorrhage (EIPH) with Furosemide (FUR) has become widespread, despite the fact that its results are questionable in efficiently and consistently controlling haemorrhage. In Brazil, Thoroughbred racehorses are entitled to the use of FUR once they are endoscopically diagnosed as EIPH positive by authorized veterinarians. A recent revision statement concerning EIPH has declared there is convincing scientific evidence that the condition is progressive and weak recommendations regarding the use of furosemide (FUR) as an effective way of managing $\mathrm{EIPH}^{2}$. This study evaluated the efficacy of first time FUR use under competition circumstances by comparing endoscopies after two consecutive races.

\section{Material and Methods}

Ethics approval was granted for conduction of this research (Wintec protocol 93) and informed consent from the people responsible for the horses was obtained. Thoroughbreds racing at Gavea Hippodrome (Rio de Janeiro, Brazil) from August to December 2006, that displayed endoscopic signs of EIPH for the first time after a race (Group FUR, R1), were included in the study. EIPH grading (0-4) was according to the

Afiliação dos autores: † Docente do Curso de Graduação em Medicina e do Mestrado Profissional em Diagnósotico Clínico e Laboratorial em Medicina Veterinária. Universidade de Vassouras. Vassouras/RJ;

§Research Associate, CHASP, Waikato Institute of Technology, Hamilton, New Zealand.

\# Veterinária Autônoma, atual Funcionária do MAPA.

Faculty of Veterinary medicine, The University of Melbourne, Melbourne, Australia.

* Email para correspondencia:mfveterinaria@hotmail.com

Recebido em: 13/04/2018. Aceito em: 09/05/2018. 
literature ${ }^{3}$. Horses in group FUR were then medicated with $4 \mathrm{ml}$ of Furosemide $(50 \mathrm{mg} / \mathrm{ml}) 4$ hours prior to their next competition. All horses included in this group were under the professional care of two of the authors at the time of evaluation and the protocols used were part of the veterinary management of the treated group. A second endoscopy (Group FUR, R2) was performed up to 30 minutes after the end of this second race. The control group (Group CON) consisted of animals with endoscopies after two consecutive races but that were not medicated with furosemide and were chosen from the pool of matched horses racing during the same period of time as the FUR group. The study included intact males, females and geldings between 2.5 and 6 years of age. There were 147 horses that met the selection criteria, however to eliminate confounding due to initial EIPH grade and to have both FUR and CON horses in each initial EIPH grade, 10 controls without initial EIPH were omitted. Fifteen FUR horses with an initial grade of 4 were also deleted due to lack of matched controls. The Mantel-Haenszel estimate of the risk ratio of a decrease in EIPH grade when comparing FUR and CON horses was calculated.

\section{Results}

A total of 96 animals were included in Group FUR and 26 were included in Group CON. Horses that received FUR had a higher chance (risk ratio $2.1,95 \% \mathrm{CI} 1.2$ to $3.8, \mathrm{P}=0.0013$ ) of presenting a subsequent lower degree of haemorrhage than horses not medicated. In Group FUR, 62 horses (64.6\%)) displayed a decrease in EIPH grade after FUR; 29 $(30.2 \%)$ did not show any difference and 5 (5.2\%) presented an increase between R1 and R2. In Group CON, 8 horses $(30.8 \%)$ displayed a decreased grade of EIPH in the second endoscopy, while $9(34.6 \%)$ did not show any difference and $9(34.6 \%)$ presented an increase between the two endoscopies.

\section{Discussion}

Furosemide's mode of action in controlling EIPH is still unclear but it has been demonstrated that is it efficient in reducing EIPH in racehorses ${ }^{4,5}$. In the present study the efficacy of FUR in reducing EIPH in racehorses receiving the drug for the first time is documented. In comparison, EIPH positive horses not receiving furosemide showed either an increase or no change in bleeding grades in two consecutive endoscopies. It has been postulated that EIPH reduced athletic performance overtime $\mathrm{e}^{6,7}$ and there is a welfare concern involving the occurrence of EIPH and the lack of treatment for the condition. Furosemide is the only approved pre-competition drug administered to EIPH positive racehorses in most racing jurisdictions making it essential that its mode of action and effects are studied in detail.

\section{Conclusions}

FUR reduced at least one grade of EIPH in $64.6 \%$ of the Thoroughbreds using the drug for the first time in competition compared with $30.8 \%$ of control horses. Horses affected with EIPH had a significantly higher chance of subsequent reduced bleeding if medicated with furosemide than controls.

\section{References}

1. West JB, Mathieu-Costello O, Jones JH, Birks EK, Logemann RB, Pascoe JR, et al. Stress failure of pulmonary capillaries in racehorses with exercise-induced pulmonary hemorrhage. Journal of Applied Physiology. 1993;75(3):1097-109.

2. Hinchcliff K, Couetil L, Knight P, Morley P, Robinson N, Sweeney C, et al. Exercise induced pulmonary hemorrhage in horses: American College of Veterinary Internal Medicine consensus statement. Journal of veterinary internal medicine. 2015;29(3):743-58.

3. Pascoe JR, Ferraro GL, Cannon JH, Arthur RM, Wheat JD. Exerciseinduced pulmonary hemorrhage in racing Thoroughbred horses: a preliminary study. American Journal of Veterinary Research. 1981;42(5):703 - 7

4. Sullivan SL, Whittem T, Morley PS, Hinchcliff KW. A systematic review and meta-analysis of the efficacy of furosemide for exercise-induced pulmonary haemorrhage in Thoroughbred and Standardbred racehorses. Equine Veterinary Journal. 2015;47(3):341-9.

5. Hinchcliff KW, Morley PS, Guthrie AJ. Efficacy of furosemide for prevention of exercise-induced pulmonary hemorrhage in Thoroughbred racehorses. Journal of the American Veterinary Medical Association. 2009;235(1):76-82.

6. Sullivan SL, Anderson GA, Morley PS, Hinchcliff KW. Prospective study of the association between exercise-induced pulmonary haemorrhage and long-term performance in Thoroughbred racehorses. Equine veterinary journal. 2015;47(3):350-7.

7. Morley PS, Bromberek JL, Saulez MN, Hinchcliff KW, Guthrie AJ Exercise-induced pulmonary haemorrhage impairs racing performance in Thoroughbred racehorses. Equine Veterinary Journal. 2015;47(3):358-65. 